\title{
Luis Saia
}

"E porque huma das couzas que as Nacçoens mais cultas costumão ter grande cuidado no tempo prezente hé a semetria, e armonia dos edeficios que de novo se levantão nas Povoaçõens das Cidades, e Villas para que da sua disposição não rezulte a comodidade publica mas tambem o agrado com que se fazem mais appeteciveis, e habeis as Povoações, conhecendo-se da sua boa ordem com q'estão dispostas a policia, e a cultura dos seus habitadores..." - Morgado de Mateus, S. Paulo, 15-9-1766 (D.I., vol. 65, p. 106)

\footnotetext{
1 PIZARRO E ARAUJO (J. S A.), Tricentenário de Paratí, DPHAN, MEC, no 22, Rio de Janeiro, 1960, pg. 46, nota 19. OLIVEIRA, J. J. Machado D', Quadro Histórico da Província de São Paulo, São Paulo, 1864, pg. 116.

2 DI, vol. XLVII, pág. 144.

3 DI, vol. XXIV, pág. 421.

4 DI, vol. LXXII, págs. 27, 28 e 45.
}

aubaté, no vale do rio Paraiba, entre S. Paulo e Rio de Janeiro, foi o principal foco de atividades bandeiristas servindo à penetração de Minas Gerais e à descoberta do ouro. A ligação imediata de Taubaté na faixa da marinha era Ubatuba. Entre as duas cidades, subida a escarpa da serra, um "mar de morros" ocupa todo o planalto, desde a serra da Bocaina até a serra de Guararema. A mesmice de toda esta área é ligeiramente modificada por algumas serras, Quebra-Gangalha, Jambeiro e Mococa, e pelas calhas dos formadores do Paraiba, Paribuna e Paraitinga, responsáveis pelo sistema de drenagem deste planalto e pela cobertura de matas que compunha a fisionomia da região desde o cabeço da serra do Mar até os campos que margeiam o rio Paraiba.

A diretriz Taubaté-Ubatuba, supostamente a serviço dos índios desde antes da descoberta, foi convertida numa trilha certamente trafegada a partir do século XVII, época em que aí são cedidas sesmarias. Com a descoberta do ouro em Minas, instalou-se um canal de escoamento nesse traçado, que no lugar chamado "Encruzilhada" abandonava o sentido de Ubatuba, dando primazia à alternativa que levava ao Porto de Parati, na divisória do litoral paulista e fluminense: a casa de Fundição de Taubaté e o Registro da Guarda para inspeção e controle já no ramo de Parati, denunciam tal movimento. ${ }^{1}$
A vila de S. Luís do Paraitinga foi localizada nessa diretriz, à beira do rio que lhe emprestou o nome, no limiar do último quartel do século XVIII, como expressão da tentativa do Morgado de Mateus de reativar a produção da Capitania de São Paulo, então restaurada e posta sob o seu comando ambicioso e progressista. ${ }^{2}$ Cunha e Paraibuna, São José dos Campos, Vila Bela da Princesa e Caraguatatuba, na banda norte de São Paulo; Atibaia e Bragança, na diretriz de Minas Gerais; Mogi Guassú e Mogi Mirim e Campinas na diretriz do caminho de Goiás; Piracicaba e depois Itapetininga, Fachina e Apiaí, nos caminhos do sul; Sabaúna e Ararapira, no litoral sul; nas baías de Paranaguá, Larangeiras e Guaratuba; Antonina, Baraquessaba, Guaratuba e Porto Novo de Cima; no planalto do sul, Santo Antonio do Registro (Lapa), lapó (Castro) e Nossa Senhora dos Prazeres (Lages) ${ }^{3}$, todas vilas fundadas a partir do citado governante, como suporte de uma pretendida revitalização da produção e da área sob o seu comando, incluindo-se nisso a perspectiva ambiciosa configurada pela colonia militar de Iguatemí. Embora tenha tomado paralelamente iniciativas destinadas a garantir resultados positivos para seus gestos de ambição: vigilância implacável e cuidados inteligentes, como o do censo de população que promoveu ${ }^{4}$, graves percalços perseguiram as ações do Morgado. Porto Novo de Cima representa um retrato de tais percalços: vila fundada e municiada 
com equipamento principal, igreja, cemitério, guias nas calçadas, não teve condições de ser populada porque o assoreamento do Nhundiaquara, que Ihe daria acesso fluvial, frustrou seu destino. Nesse conjunto, as vilas da baixada paranaense visavam a produção de farinha de mandioca, ou de pau, como diziam, munição essencial para a guerra que estava na mira do Morgado, preocupado com Iguatemi.

* O "Ensaio d'um quadro estatístico da Província de São Paulo" foi um amplo levantamento da população e das atividades econômicas realizadas em São Paulo, feito por Daniel Pedro Muller em 1937. (Nota da Risco)

5 DI, vol. LV, pág. 203. SAINTHILAIRE, Segunda Viagem a São Paulo e Quadro Histórico da Província de São Paulo. Biblioteca Histórica Paulista, vol. VI, S. Paulo, 1954, pág. 57

6 MULLER (Daniel Pedro,) Ensaio d'um Quadro Estatístico da Província de São Paulo, S. Paulo, 1923, págs. 125 e 130.

7 Cartório do 20 Ofício, São Luís do Paraitinga, Livro no. 54 , fl. 8 .

8 DAESP, População, cx. 160, ord. 160, anos 1814/1843, mss. 1822.

9 Inventários, 20 Ofício, São Luís do Paraitinga, ano 1828.

10 Inventários, 10 Ofício, São Luís do Paraitinga, ano 1909, doc. 1770.

11 Inventários, 10 Ofício, São Luís do Paraitinga, doe. 1770, fl. 25 .

12 SAIA (Luís), Morada Paulista, col. "Debates", ed. Perspectiva, São Paulo, 1972, págs. 165 e seguintes.

13 DAESP, População, cx. 159, ord. 159, mss. 1813, 2o Cia. de Ordenanças.

14 Livro de Vereanças, São Luís do Paraitinga (18001814), fl. 24.
Diversamente daquilo que ocorria na bacia de Paranaguá, as cidades paulistas fundadas pelo Morgado de Mateus ganhariam substância com a produção de açucar e cereais, num compasso de espera, até que o café Ihes trouxesse uma produção colonial volumosa. Produção de açúcar e cereais, bem assim um criatório ralo, apenas aqui e ali mais avivado pela exportação de toucinho, queijo e fumo, e desta região transportados para Taubaté e Ubatuba no lombo de bestas, em bruacas, jacás e canudos ${ }^{5}$. Ao tempo do Quadro Estatístico de Daniel Pedro Muller ${ }^{*}$, já bem entrado o século XIX, no seu segundo quartel, com a zona de Bananal, Areias, etc., plenamente invadida pelos cafezais, e suas cidades florescentes, a área de S. Luís oferecia o quadro de uma produção de 16.000 arrobas de café, com três fazendas principais e mais duas distilarias de aguardente. ${ }^{6} \mathrm{O}$ domínio era completo para a produção de subsistência, com pequeno excedente comerciável. A fisionomia regional de "mar de morros" cobertos de matas teria sido ligeiramente afetada pela abertura de clareiras e de destruição pela coivara. É nesses morros e aproveitando o humus dessas matas que vai se instalar o grosso da produção cafeeira que faria a riqueza de S. Luís do Paraitinga.

Dos testemunhos da primeira fase de instalação da vila e de ocupação da região, restavam até pouco tempo dois edifícios: a fazenda Pedro Alves e a Igreja das Mercês, a primeira instalada a beira-rio, a segunda no sopé do morro que constrangia o âmbito urbano no reduzido terrapleno existente, aí, junto à calha do Paraitinga.

Um dos documentos mais antigos que se conseguiu a respeito da fazenda Pedro Alves, data de 1809. Trata-se de uma escritura de compra e venda de terras na paragem Santa Cruz, "que Principiam aonde se acabam as terras de Salvador Alves". ${ }^{7}$ Este Salvador Alves (Ferreira), que aparece como proprietário de um engenho ${ }^{8}$ e cujo inventário, de 1828, menciona "casas de citio com benfeitorias engenho que foi visto e avaliado"9, e era pai de outro de mesmo nome, por sua vez, pai de Pedro Alves Ferreira, e cuja mulher, Ana Joaquina de Andrade, falecida em 11-9-1908, levou ao inventário que refere "uma chácara além da ponte desta cidade". ${ }^{10}$ No auto de avaliação correspondente vem mencionada "uma chácara onde reside o cidadão Pedro Alves Ferreira (...) no bairro do Turvo". A casa de morada dessa chácara — isto vem igualmente mencionado - era "toda coberta de telhas, assobradada', relacionando ainda os móveis: "1 marqueza estreita, 1 marqueza estragada, 1 mesa de jantar velha, 1 armário, 1 catre e 1 par de canastras velhas". Esta residência chegou a ser documentada pelo IPHAN em 1946, época em que não havia mais sinal de engenho, mas existia uma pequena capela para cujo patrimônio o inventário de 1909 deixa "uma reserva de vinte braças". ${ }^{11}$ Jamais me perdoarei não ter promovido seu tombamento. Devia te-lo feito, em que pese se tratar de uma peça de interesse estritamente regional. ${ }^{12}$ Foi demolida há uns 10 anos.

A capela das Mercês foi documentada numa história manuscrita, de autor desconhecido, que existe no Museu de São Luís do Paraitinga: "Relato da História de São Luís do Paraitinga de 1686 a 1913". No capítulo - Edifícios - se lê: "Capella das Mercês — Em 1808 chegaram a villa nova de S. Luís a velhinha Maria Antonia dos Prazeres e uma filha por nome Izabel que vinham da villa de Guaratinguetá para rezidirem aqui - Maria Antonia trouxe uma imagem de N.S. das Mercês (...) Em 1809 Nha Antonia ajudada pela família Pereira e devotos, começaram a edificar a Capella (...) e em 1814 foi inaugurada". Tal relato vem sofrer correções pelos textos de documentos oficiais onde, num deles, de 1813, encontramos Maria Antonia dos Prazeres, aos 62 anos de idade, morando no Bairro da vila onde vivia das agências de seu filho, e com 2 escravos, dada como natural de "Caithé" (Minas Gerais). ${ }^{13}$ Por outro lado, a Capela das Mercês seria, na verdade, anterior à data "tradicional", posto que já em 1801 aparece uma reclamação respeitante ao "esgoto das agoas que empedem a servidão do povo na Rua que vai da ponte para a capella de Nosa Senhora das Merses". ${ }^{14}$ Além disso, d. Maria Antonia aparece como "Protetora da Senhora das Mercês", requerendo à Câmara "um pedaço de terreno para ajuda do Patrimonio da mesma Senhora, ao que se deferiu concedendo-lhe seis braças de 
15 Livro de Vereanças, São Luís do Paraitinga (18001814), fls. 242, 242v, 250 e 250v, ano de 1814.

16 "Lançamento da Receita da Dessima dos Predios Urbanos da Vila de São Luís, para o Anno finansseiro do 10 de julho de 1841, a 30 de junho de 1842", rua da Quitanda, n. 17.

17 Inventários e Testamentos, Cartório do 10 Ofício, São Luís do Paraitinga, ano de 1840 .

18 Inventários, Cartório do 10 Ofício, São Luís do Paraitinga, ano de 1846, fl. 22.

19 Livro de Provimentos Gerais, posturas da Câmara e contratos, ano de 1834, fol. 16, art. 10; e ano de 1854, fl. $20, \S 10$.

20 DAESP, Ofícios Diversos, São Luís do Paraitinga, cx. 470, ord. 1265 , ano de 1835.

21 Livro 10 do Tombo, São Luís do Paraitinga, fl. 13. terreno" e mais, que atentando à segurança da dita igreja, queria-se fazer o corredor dela. ${ }^{15}$ Embora tal capela tenha sido objeto de reformas sucessivas e desfiguradoras, mantem sua validade integral, do ponto de vista de referência certa para análise da estrutura urbana.

Como testemunho do período anterior ao café deve ser mencionado ainda o sobrado da Praça (Osvaldo Cruz n`2) atualmente desfigurado por uma platebanda com ameias. Na décima urbana de $1841^{16}$ se encontra o fogo de Manoel José Pereira, cujo testamento (1840) conta que tem casa de sobrado no centro da vila ${ }^{17}$ e cujo inventário, de 1846 cita "umas moradas de casas de sobrado com seis portas na frente, três em baixo, três em cima citas na rua da Quitanda em o largo da Matriz". ${ }^{18}$ Tal sobrado tem um pé direito de 6,40 $\mathrm{m}$. pelo que se distingue dos demais sobrados que obedeciam as posturas de 1834 e 1854 que mandavam:

\section{Postura de 1834 - art. $1^{\circ}$}

"os edificios serão levantados de taipas, madeiras ou pedras, e as casas terreas terão dezoito palmos de altura para cima, e as de sobrado 34 ..."

Postura de 1854 - folha $20-\S 1^{\circ}$

"os pés direitos nunca terão menos de 18 palmos da soleira à sacada do telhado, e sendo de sobrado poderão ter os pés direitos de 16 palmos sendo sempre as soleiras levantadas da terra pelo menos 1 palmo, e calçada de pedra". 19

Os edifícios citados, a igreja do Rosário, a matriz, a casa de Câmara e Cadeia (cujo local primitivo se sabe qual era), o próprio rio que tangencia a Cidade, e as ruas que podem ser identificadas por tais elementos confrontados com a documentação primária encontrada, são pontos fixos que servem à identificação dos imóveis e dão as indicações suficientes sobre a estrutura urbana de São Luís do Paraitinga.

O termo de ereção da vila, de 31 de março de 1773, conta que se levantou o pelourinho, "um madeiro grosso quadrado e Lavrado de quatro faces de pau de Lei chamado de peroba, com quatro braços em cada face, e um cutelo no alto do remate olhando para Oeste na forma determinada pela Lei, e Ser aquele Lugar destinado o melhor por ficar fronteando todo o Circuito da Praça por se achar esta Vila fundada Tantos as ruas como a arrumação das casas pela direção que mandou o mesmo llustríssimo, e Exmo. Senhor que em tudo se Seguio pela admirável formalidade com que o mesmo Ilustríssimo Sr. com a Sua doutissima idéia fundou no seu pensamento tão acertada, e justa fundação a qual se acha já com Cinqüenta, e duas Casas, além de varios Lugares Limpos para Se Levantarem avultado número de Casas pelo gosto, e alegria em que na dita Vila se querem Estabalecer todos os Povoadores pela festividade de terras, e alegria do terreno, e Saude que nele logram todos até o presente Cousa maravilhosa que em três anos perto de quatro não tem havido molestia em todos os Povoadores, e Suas familias que Ihes tenha causado Despesa em procurar, medicinas e o dito Pelourinho fincado olham as duas faces de Norte a sul, e outras duas de Leste, a Oeste, e fazendo o dito Pelourinho Pião o dito Juiz fundador, e administrador, a beneplacito de todos os Povoadores, consignou de Rocio, a dita Vila correndo pelo Rio abaixo seiscentas braças no Rumo do Sul Sudeste, e quatrocentas braças do Pelourinho para Cima do Rumo norte nordeste, e do mesmo pelourinho para Leste oeste duas mil braças para reditos do conselho dando-se de foro a quem as quiser ficando Livre e sem pensão alguma, as Casas que Se quiserem fazer com seus fundos para Quintais, tudo em virtude da mesma Portaria que a ele Juiz fundador, e administrador foi enviada pelo mesmo llustríssimo, e Exmo. Sr. General desta Capitania..." 20

A ereção oficial da vila, expressa pelo documento citado, representou uma correção da situação de fato existente, posto que já contava a localidade com 52 casas. Tanto tais habitações como as daqueles que em 1772 pedem um pároco que lhes administre sacramentos e que são povoadores do sertão ${ }^{21}$, nada indica que estivessem alinhadas de acordo com alguma norma ou idéia de conjunto, previamente estabelecida. Que os povoadores, de início estabelecidos na paragem, não estariam dispostos numa situação semelhante ao que se poderia chamar de arcabouço urbano, há sinais seguros, inclusive e principalmente o próprio rigor com que posteriormente são tratadas as questões do alinhamento. O que se vê, por volta de 1780, quando a Câmara é solicitada pelo governo da Capitania 
22 Livro de Vereanças (17761785) e Rematações (17771792), São Luís do Paraitinga, fl. $48 \mathrm{v}$.

23 Idem, fl. 32v, ano de 1778.

24 Livro 10 do Tombo, São Luís do Paraitinga, fl. 74, ano de 1774.

25 DI, vol. LXIV, págs. 79 e 95.

26 DAESP, Ofícios das Câmaras de Lorena, São Luís, Ubatuba, etc., anos 1721/1822, cx. 7, ord. 233, doc. 7-3-24.

27 Livro do Registro Geral da Câmara, São Luís do Paraitinga, 1828/1873, fl. 148

28 DAESP, Ofícios das Câmaras de Lorena, São Luís, etc., 1721/1822, Pasta 3, doc. 7-3-19.

29 Autos de Requerimentos, Cartório do 10 Oficio, São Luís do Paraitinga, ano de 1801, fl. 16v.

30 DI, vol. LV, pág. 83.

31 Livro do Registro Geral da Câmara, São Luís do Paraitinga, 1828/1873, fl. 155 (22.10.1838).

32 Livro de Atas da Câmara, São Luís do Paraitinga (18291839), fls. 29, 29v, $37 \mathrm{v}$ a 44 , $85,86 v$ e 87.

$33 \mathrm{Idem}, \mathrm{fl} .120 \mathrm{v}$ (21.11.1833).

34 DAESP, Ofícios Diversos, São Luís do Paraitinga, cx. 471, ord. 1266, Pasta de 1839, ofício de 12.8.1839.

35 Inventários, Cartório do 10 Ofício, São Luís do Paraitinga, ano de 1840 (testamento), fl. 2 e 3. a "Respeito de poder haver ou não capitam mor" na vila, é a informação de que "nesta vila não há carencia de Capitam mor pela decadencia da mesma villa porque nesta villa só se achão dez cazas de telhas fechadas e tres cubertas de capim e as mais com seos Esteios fincados desde o principio da villa e não podem Redificar nem Levantar..." 22 E nesses nove ou dez anos depois de fundada a vila e aberto um caminho novo que alcançava a povoação pelo rio abaixo, com ponte sobre o Turvo (sic), caminho esse que ainda aparece numa planta de 1850, surge um problema com os moradores do caminho velho, "o primeiro por onde se começou esta povoação" 23. fora trancado por um tal Vicente Ferreira, com prejuizo para os 12 moradores aí estabelecidos. Uma petição do vigário da vila protesta contra a situação emergente.

Esta correção da instalação original dos colonos é coisa comum na vida colonial e povoa a história com expressões como caminho novo, vila velha, etc. No presente caso, de vilas fundadas por iniciativa do governo e segundo uma idéia preestabelecida de colonização - e este é o caso específico do Morgado de Mateus - a racionalidade que transpira no texto do termo de ereção de São Luís, representaria um reflexo do iluminismo europeu que desembocaria na revolução francesa e que povoaria a cabeça de um estudioso como Luís Antônio de Souza Botelho Mourão, o Morgado de Mateus. Antes do século XVIII, salvo uma ou outra iniciativa do governo metropolitano, e em contraposição ao que acontecia na América Espanhola, onde a colonização era orientada pelo espírito organizado das Leis das Índias, a formação das cidades brasileiras era matrizada pelo empirismo da geografia, do sítio escolhido, da topografia e do rendimento imediato da instalação. $\mathrm{O}$ virus instilado pelo racionalismo do Morgado de Mateus perseguiu a vila de São Luís do Paraitinga, onde se estabelece uma luta surda entre o que os dirigentes chamam de "elegância" da praça, das ruas e da cidade, e o interêsse imediatista dos moradores, sempre dispostos a se aproveitar das circunstâncias para receber um quinhão mais refarto da situação urbana. Em 1774, um ano apenas depois de ereta a vila o Juiz Medidor Manoel Antônio de Carvalho baixa um edital em que faz saber "a todas as pessoas que tem tomado chãos de terra para fazer casas e as não tem levantado dentro de três meses as ponham cobertas e do Contrário se dará a quem as queira levantar principalmente nas ruas principais e nos cantos das próprias ruas" . ${ }^{24}$ O que aconteceu com a praça e o adro da matriz, cujo acabamento se prolongou por toda a primeira metade do século XIX, é uma expressão dessa luta.

A matriz, provalvemente edificada em termos precários desde a primeira hora ${ }^{25}$ foi uma das preocupações da cidade. Ao fim do governo de Bernardo de Lorena, por 1797, pretendendo-se "fazer nova Matriz, por ser a antiga muito pequena, da creação da Vila, e já arruinada, o Reverendo Vigario daquele tempo fez abolir o corpo da Igreja, em razão de alargar o terreno para a nova, deixando somente a Capela Mor: e dando-se princípio às paredes de Taipa, se não pôde conseguir pela incapacidade da terra, perdendo-se o que se achava feito..." $26 \mathrm{Com}$ lugar previamente destinado ${ }^{27}$, ainda em 1800, os vereadores se declaram consternados principalmente pela falta de Matriz e "obrigados / grande parte dos mesmos / a assistirem ao Sto. Sacrifício da Missa expostos ao Rigor do Tempo". ${ }^{28}$ Em 1801, o "colono e Povoador" Antônio Domingues de Castro, português casado em Sabará, declara que trabalhara como pedreiro (que era seu ofício) na construção da matriz. ${ }^{29}$ Em 1803, numa carta à Câmara de São Luís, o governador Franca e Horta proteje a construção da nova matriz assegurando "não mandar fazer ali nenhum recrutamento enquanto o Povo nela trabalhar, e a nossa Monarquia estiver em Paz". ${ }^{30}$ Esta segunda tentativa foi depois demolida "por ser superior às forças do Povo". ${ }^{31}$ Em 1830 se decide afinal sua reconstrução. ${ }^{32}$ Três anos depois, a quem pede uns chãos no local, a câmara resolve que somente depois de demarcada a nova matriz, para o que o povo já aplainara o terreno, é que isso deve ser resolvido. ${ }^{33}$ Em março de 1839, "em virtude do mandado da Camara Municipal, e por resolução da mesma, e em cumprimento do Oficio do Exmo. Senhor Governador desta Provincia, em data de 18 de dezembro de 1838 (...) para efeito, de se proceder na Demarcação do Adro, que deve ficar livre, para a Elegancia da Igreja Matriz, e Pateo principal (...) foi determinado ao Arruador Antonio Mariano Bueno, que procedesse ao Alinhamento, seguindo a linha da Rua do Império, a entestar com a Rua Lateral do Rosario, e que de parte da Rua da Praça seguisse o Alinhamento das casas do falecido Cap. Mor Joze Gomes de Gouvêa a entestar com a mesma Rua do Rosario..." 34 Em 1840, no inventário de Manoel José Pereira, se lê: "deixo para a coberta da Igreja Matriz desta Vila que se está principiando... ${ }^{35}$ 
36 Livro de Provimentos Gerais, posturas, e contratos da Câmara, São Luís do Paraitinga, ano de 1831, fl. 10, art.o 12 .

37 " 'Relato da História de São Luís do Paraitinga de 1686 a 1913" (manuscrito), capítulo — Edifícios.

38 Livro de Vereanças, São Luís do Paraitinga (18151829), fl. $215 \mathrm{v}$ e $225 \mathrm{v}$, ano de 1827.

39 DAESP, Ofícios Diversos, São Luís do Paraitinga, cx. 470, ord. 1265, ano de 1828.

40 Livro de Atas da Câmara, São Luís do Paraitinga (18291839), fl. 276 (12.5.1839).

41 Livro de Atas da Câmara, São Luís do Paraitinga (avulso), de setembro de 1849 a dezembro de 1850, fl. s/ no, 50 sessão, de 5.4.1850; e Livro da Atas da Câmara, São Luís do Paraitinga (1841-1867), anos de 1841, $1857,1860,1861,1862$, respectivamente fls. 12, 55, 131 , $135 \mathrm{v}, 136,177$ e $188 \mathrm{v}$.

42 Livro de Atas da Câmara, São Luís do Paraitinga (1841-1867), anos de 1863 e 1867 , respectivamente fls. 204 e $387 v$.

43 Papéis avulsos, Câmara de São Luís do Paraitinga, ofício de 18.4.1871.

44 Testamentos, Cartório do 2. Ofício, São Luís do Paraitinga, Livro n. 54, anos 1809/1812, fl. 76, ano 1811

45 Livro do Registro Geral da Câmara, São Luís do Paraitinga (1806-1826), fl. 127, registro de carta de data, de 7.8.1815.

46 DAESP, Poder Judiciário, Juízes de Lorena, Areias, Guaratinguetá, etc., Pasta 2, doc. 74-2-5 (de 6.4.1784).

47 Livro de Registro de Cartas de Data de Terras, São Luís do Paraitinga (1816-1910), registro de 4.2.1834

48 DAESP, Ofícios Diversos, São Luís do Paraitinga, cx. 471, ord. 1266, Pasta de 1849 (of.o de 8.11.1849) e Pasta de 1850 (Of.o de 6.4.1850).
Outros documentos manifestam igual preocupação de liberar a envoltória da igreja, a fim de preservar sua postura. ${ }^{36}$ Já em fins do século passado a igreja matriz, então construída, recebeu novo tratamento arquitetônico ${ }^{37}$, mantendo entretanto o local, porém não a posição que a definira no início da vida de São Luís.

O mesmo não ocorreu com a casa de Câmara e Cadeia. Essa mudou de lugar, pulando da frente da igreja para um lugar que seria a trazeira do templo, se este permanecesse com o frontespício voltado para o Sul. Na verdade, uma vez decidida a nova direção deste frontespício, voltado para Oeste, houve um remanejamento geral do binário matriz-praça e foi em função deste novo arranjo que se configurou o centro principal de São Luís. Essa cadeia estava atrás do pelourinho, indicam antigos documentos. ${ }^{38}$ Para esta construção, o governo provincial enviou à Câmara de São Luís, em 1828, um projeto. ${ }^{39}$ Mas ainda em 1839 a cadeia estava funcionando, provisoriamente, muito distante do centro, "sem comodidade alguma para os presos e guardas, e sem segurança alguma". ${ }^{40}$ Numa reunião da vereança, em 1850, o assunto da cadeia foi discutido: sua construção estaria arrematada "de quatro para cinco anos e não se acabava, o que somente ocorreu em $1860^{41}$, para ser destruída por uma enchente em 1863. ${ }^{42}$ Para a sua reconstrução, já agora na outra banda da matriz, a Câmara recebeu novo projeto, em 1871. Sobre esta matéria a Câmara envia ao Presidente da Província, em 18-4-1871, um ofício que diz: "Tendo a Camara Municipal desta Cidade resolvido em sessão de hoje dar principio às Obras da Cadeia, e considerando que não pode ela ser Edificada no lugar onde existiu a antiga por ser sujeita às inundações do rio que circula esta Cidade, e atendendo ao Conselho de V. Exa.; resolveu tambem comprar os terrenos pertencentes ao Tte. Flavio José de Toledo com as paredes existentes e madeiramentos, bem como os terrenos pertencentes aos herdeiros do finado Padre João Roiz de Morais anexos a aqueles, situados ao lado da Igreja Matriz desta mesma cidade e em lugar elevado e proprio para edificios semelhantes, pela quantia de 4:000\$ rs., sendo tres contos e setecentos pelo terreno e casa do dito Toledo, e $300 \$ 000$ pelos outros..."43 Este edifício, cujo projeto se encontrou, com a respectiva memória, foi demolido em época recente para que em seu lugar se construísse um Centro de Saúde.
A igreja do Rosário, cuja posição e acesso (ruas) constituem outros dados fixos e sabidos para a análise da estrutura urbana de São Luís, teve a sua primeira instalação na segunda década do século XIX. Em 1811, na declaração de última vontade de Ignês Ferreira de Castilho se lê: "que seu marido Francisco Jorge dos Santos Logo que ela falecesse tomasse posse de (...) seis escravos, e um Citio, e Casas da Vila, e umas cabeças de gado, e tres cavalos, e duas salas, e um forno de Cobre e duas Panelas de ferro, e um tacho, e um Nicho com quatro imagens, uma Balança com oito libras de peso duas caixas, e o que mais houver (...) fazendo sepultar seu corpo na Capela de Nossa Senhora do Rosario caso no tempo de meu falecimento ja esteja Benta, e se não estiver sera na Matriz desta Vila..." 44 Já em 1815, o registro de uma carta de data de terras menciona a "nova rua que vai do Rosario para as Mercês" 45 .

Além destes pontos documentadamente bem localizados, e de outros como as pontes antiga ${ }^{46}$, que aparece na planta da cidade de 1850, e a nova que neste gráfico é indicada como pretendida, os problemas de datas de chãos cujas confrontações esclarecem sobre os proprietários e construções, as próprias ruas se configuram como dados fundamentais para a marcação da estrutura urbana. Nessa época, 1850, praticamente a disponibilidade local de áreas para construir estaria esgotada, inclusive com o aproveitamento de locais alcantilados, como o da residência em que depois morou Osvaldo Cruz e que existia em $1834^{47}$, dada inicialmente como prédio rústico destinado à agricultura, mas que originou uma rua chamada Boa Vista. Dessa ocupação intensiva partiu certamente o morador Rochalles de Souza e Silva para uma tentativa de lotear o outro lado do rio Paraitinga. ${ }^{48}$

As ruas fundamentais para a marcação da estrutura urbana foram:

1) Rua da Ponte. Provavelmente vinculada ao caminho de Ubatuba, desde o início da Vila é chamada rua da Ponte ${ }^{49}$ (que assistia na sua extremidade noroeste), ou, por vezes, de Mercês, como num documento de $1834 .{ }^{50} \mathrm{Em} 1859$ é nomeada rua Direita $^{51}$ e com este nome vai até $1873^{52}$, para, no ano seguinte ${ }^{53}$, receber o nome de 31 de Março, com que prossegue por muito tempo. ${ }^{54}$ Atualmente é a rua Cel. Domingues de Castro, como sempre a saída principal para Ubatuba. 
49 Escrituras, Cartório do 20 Ofício, São Luís do Paraitinga Livro no 54, anos 1809/1812, fl. 97, ano 1812

50 Livro de Registro de Cartas de Data de Terras, São Luís do Paraitinga (1816.1910), registro de 4.2.1834.

51 Escrituras, Cartório do 20 Ofício, São Luís do Paraitinga, Livro no 48 , fl. 14, ano 1859.

52 Escrituras, Cartório do 20 Ofício, São Luís do Paraitinga, Livro no $23, \mathrm{fl} .73$, ano 1873.

53 Escrituras, Cartório do 20 Oficio, São Luís do Paraitinga, Livro no 55, fl. 7v, ano 1874.

54 Livro de Provimentos Gerais, posturas, e contratos da Câmara, São Luís do Paraitinga, fl. 184v, ano de 1895.

55 Livro do Registro Geral da Câmara, São Luís do Paraitinga, (1806-1826) fl. 127, registro de carta de data de terra, de 7.8.1815; Escrituras, Cartório do 20 Ofício, São Luís do Paraitinga, Livro no 66 , fl. 26 , ano 1894.

56 Escrituras, Cartório do 20 Ofício, São Luís do Paraitinga, Livro no 5, fl. 110, em 18.5.1838.

57 Livro de Atas da Câmara, São Luís do Paraitinga (1841-1867), fl. 24v, sessão de 19.6.1855.

58 Papéis Avulsos, Câmara de São Luís do Paraitinga, ofício de Fiscal da Câmara aos srs, vereadores, de 4.7.1832; e Atas da Câmara (avulso) de maio de 1842 a abril de 1843, fl. s/n. 4a sessão ordinária demaio de 1842 .

59 Inventários, Cartório do 2o Ofício, doc. 1283, fl. 52, ano 1886

* Palmo: antiga medida de comprimento correspondente a 8 polegadas ou 0,225 m. Cf. Corona \& Lemos; Dicionário da Arquitetura Brasileira. São Paulo: Editora e Distribuidora Art Show Books Ltda., 2 ${ }^{a}$ ed., 1989. (Nota da Risco)
2) Rua do Rosário. Aparece invariavelmente com este nome ${ }^{55}$, embora sua denominação seja por vezes tumultuada pelo fato de ser indicada como levando às Mercês. ${ }^{56}$ Com a abertura da rua dos Fazendeiros ${ }^{57}$ foi prolongada para além da rua da Ponte, chegando até as margens do Paraitinga. É a atual rua Monsenhor Gióia.

3) Rua da Cadeia ou Beco da Cadeia ${ }^{58}$, depois nomeada rua D. Pedro 11 59, sendo atualmente denominada rua 31 de Março. No plano primitivo da cidade, aí foi instalado o pelourinho, a cadeia ficando atrás, com frente para a matriz. Foi também denominado Largo da Forca ${ }^{60}$, e Largo da Cadeia ${ }^{61}$, no espaço mais largo que ficou livre com o remanejamento geral desta quadra. Este Largo da Forca, depois da União62, e agora Largo Euclides Vaz de Campos, na Décima Urbana de 1841 não aparece.

4) Rua do Comércio. Em documento de venda de casa, de 1811, já comparece, como rua da Quitanda. ${ }^{63} \mathrm{Na}$ Décima Urbana permanece o nome, depois convertido em rua do Comércio. ${ }^{64}$ Começava ao "pé da ponte" que rematava a rua da Ponte ${ }^{65} \mathrm{e}$ terminava no ponto que depois se aproveitou para a construção da ponte nova - o chamado beco do Império ${ }^{66}$ - conforme pretensão exarada na planta de $1850 .^{67}$

5) Rua da Praça. De ambos os lados do Páteo ou Praça da Matriz. ${ }^{68}$ A definição do Adro e das ruas que ladeiam a igreja matriz foram objeto de pendência. Em 1833, alguns interessados reiteram o pedido de chãos aí, cada um deles "cinquenta palmos de terreno, entre o lugar designado para matriz, e a nova cadeia". ${ }^{69}$ A Câmara reunida em 21-11-1833, resolve "que depois de principiada, ou demarcada a nova matriz voltassem para serem deferidos". ${ }^{70}$ Efetivamente a matriz primitiva teria seu eixo a $90^{\circ}$ do atual, ficando livre um espaço entre ela e a cadeia-pelourinho. A pretensão era simplesmente ocupar esse intervalo, "entre o lugar designado para matriz e a nova cadeia". Três anos depois, apesar da oposição de outros proprietários, antigos donos da situação política, já se havia feito um movimento de terra no sítio do terreno "aplainado pelo Povo, e destinado para a obra da Igreja"71, e mudado a direção do templo, conforme trata um documento justificativo: "Acontece que há longos anos Foi feito um desaterro pelos Povos para nele plantarem, a
Matriz, o que não conseguiram, Sim de presente é mudada sua direção tem principiada a Capela-mor, e Corpo da Igreja ja marcado, e restam do alem do Pateo que deve ficar, aos lados da mesma uma porção de terreno que admite dois alinhamentos de Ruas (...) houveram varios requerimentos de Cidadãos, pedindo Datas para, edificarem suas casas que muito Servem para formosiar, a praça, mesmo delas pagarem emolumentos à Nação..."72 Resolvida a mudança, houve larga distribuição de terrenos a parentes e amigos. Mais tarde, em 1838, o sr. Castro, que naturalmente votara a favor dos pretendentes, retira o voto que dera em favor de seus íntimos. ${ }^{73}$ Estourado o escândalo, sugere-se cometer ao Presidente da Província a tarefa de resolver o assunto, instruindo a informação com os pareceres do pároco e do fabriqueiro da matriz, a fim de que se resguarde "toda a elegancia do Pateo principal deste Municipio". ${ }^{74}$ Como sempre, agiam os açodados interessados, alegando urgência na construção de suas moradas. Por um ofício dirigido pela Câmara ao Presidente da Província se verifica que todos os requerentes tem moradas na cidade, "exceto o padre (Morais) e José Basilio, este até ja não mora neste Municipio, por se ter mudado para o de Ubatuba ${ }^{75}$, todos empenhados em "distrair a atenção do fim a que esta Camara se dirige, que é não consentir que com tais edificios se tolha a vida e elegancia da Praça que fica de fronte do Frontespicio que deve ter a Igreja principiada porque a Praça que os suplicantes denominam — Pateo — com 330 palmos* de comprido e 310 de largo, fica muito mais baixa que o nivel do pequeno Adro da Igreja e por isso não se deve confundir a dita Praça com - Adro, como pretendem os suplicantes". ${ }^{76} \mathrm{~A}$ Câmara cassou os títulos concedidos. ${ }^{77}$ A muito custo se conseguiu uma reserva de terrenos nos laterais da igreja matriz, em que pese o desfavor de, cedidos tais terrenos, a terra para as taipas terem que vir de longe. ${ }^{78}$ Afinal em 1839 foi o terreno demarcado, em "virtude do mandado da Camara Municipal e por resolução da mesma, e em comprimento do oficio do Exmo. Senhor Presidente desta Provincia, em data de 18-12$1839 " .{ }^{79}$ Para rematar o fato consumado aparece outro documento: um requerimento do Cap. José Lopes Figueira de Toledo, e outros, pedindo a "demarcação dos terrenos que Ihes foram concedidos, no Lado esquerdo do Pateo da Igreja na conformidade da Portaria de 5-3-1840" ${ }^{80}$ 
60 Relatto da Historia de São Luís do Paraitinga de 1686 a 1913, § "Edificios".

61 Idem.

62 Escrituras, Cartório do 20 Ofício, São Luís do Paraitinga, Livro no 26, fl. 31, ano 1879.

63 Escrituras, Cartório do 20 Ofício, São Luís do Paraitinga, Livro no 54, fl. 63, ano 1810.

64 Escrituras, Cartório do 20 Ofício, São Luís do Paraitinga, Livro no 57, fl. 47, ano 1861.

65 Inventários, Cartório do 20 Ofício, São Luís do Paraitinga, doc. 783, fl. 10v, ano 1868.

66 Escrituras, Cartório do 20 Ofício, São Luís do Paraitinga, Livro n. 55, ano 1874.

67 DAESP, Ofícios Diversos, São Luís do Paraitinga, cx. 471, ord. 1266, Pasta de 1850 (Of. de 6.4.1850).

68 "Lançamento da Receita da Dessima dos Predios Urbanos", ano de 1841.

69 Livro de Atas da Câmara, São Luís do Paraitinga (18291839), fl. $120 \mathrm{v}$, sessão de 21.11.1833.

70 Idem, idem.

71 Idem, fl. 39v a 43v, ano de 1830.

72 Livro de Registro Geral da Câmara, São Luís do Paraitinga (1828-1873), fl. 303, ano 1836 .

73 Livro de Atas da Câmara, São Luís do Paraitinga (18291839), fl. 255v, sessão de 27.8.1838.

74 Idem, idem.

75 Livro do Registro Geral da Câmara, São Luís do Paraitinga (1828-1873), fl. 148.

76 Idem, idem.

77 Livro de Atas da Câmara, São Luís do Paraitinga (18291839), fl. 255v, sessão de 27.8.1838.

78 DAESP, Ofícios Diversos, São Luís do Paraitinga, cx. 471, ord. 1266, Pasta de 1839 (Of. de 12.8.1839).
Em conseqüência desta mudança, o terreno da cadeia ficou separado do espaço inicialmente estabelecido como área livre. A cadeia teria que ocupar outro terreno, como realmente ocorreria, à esquerda da matriz.

Ao tempo do lançamento da Décima Urbana, em 1841, a cidade estava portanto com a sua estrutura armada, inclusive com a rua do Catumba, atual rua do Carvalho, que era simétrica da rua do Rosário no acesso a esta igreja.

Na rua Boa Vista, no topo da qual se estabelecera, a partir de 1826, o Ajudante Joaquim José Ferreira, na casa em que futuramente nasceria Osvaldo Cruz, aquele morador relutou em se considerar participante da órbita urbana. Seus cafés (6.000 pés) e plantações, o alcantilado do sítio que escolhera, e o que teria que pagar em função dos escravos e produção, pretendia que o eximissem das obrigações de contribuinte urbano. Embora, é claro, levasse as vantagens da cidade ali aos seus pés. ${ }^{82}$

Em 1841, pela Décima Urbana, era a seguinte a ocupação da área da cidade, traduzida em ruas e número de prédios correspondentes a cada uma delas: Rua da Quitanda, 33; rua da Praça, 13; rua da Ponte, 49; rua do Rosário, 37; rua do Catumba, 45; rua da Boa Vista, $1 .^{83}$ Em 1844, por um ofício do Juiz de Paz ao Pres. da Província, se sabe que, na vila, dividida em quarteirões, o número de fogos era o seguinte: $1^{\circ}$ quarteirão, 100 fogos; $2^{\circ}$ quarteirão, 64 fogos; aditamento, 16 fogos. ${ }^{84}$ Foi provavelmente nessa época que a região foi tomada pela cultura do café, em que pesem aqueles 6.000 pés de café do Ajudante J. J. F erreira, em 1840. Em 1852, com uma produção de 6.000 arrobas, as maiores fazendas de café seriam as seguintes: a do padre João Roiz de Morais, a do alferes Manoel Pereira de Castro, a do ajudante Luís Gomes de Gouvêa e a do Cap. mor José Lopes Figueira, as quais "vão seguindo sofrivelmente". ${ }^{85} \mathrm{~A}$ atual sede da fazenda Pinheirinho, cujos elementos construtivos e organização do espaço a aproximam da sede da fazenda Pedro Alves, pelo que deve ser interpretada, pelo menos por enquanto, como sede de antigo engenho do início do século XIX, teria sido igualmente sede de uma fazenda de café. Caso comum, de resto; antigo engenho aproveitado para a cultura do café. $^{86}$
Das informações encontradas depreende-se que na década de 40 da centúria passada, a estrutura urbana de São Luís já estaria inteiramente moldada, com ruas e logradouros perfeitamente definidos, bem assim os diferentes setores da cidade já caracterizados na sua função citadina. Pouca coisa do que aconteceu dessa época em diante foi capaz de introduzir modificação sensível; nem os sumidouros que surgiam nas ruas sem calçamento ${ }^{87}$, nem a feitura de uma ponte sobre o rio Paraitinga em nova localização. ${ }^{88} \mathrm{O}$ páteo da matriz repartia com a rua da Ponte, a preferência para as melhores habitações. ${ }^{89} \mathrm{Nem}$ mesmo a abertura de uma rua Nova, entre a rua da Ponte e o rio, paralela àquela, a rua nova Municipal, ou rua dos Fazendeiros, nem mesmo essa mudança veio atingir a estrutura já estabelecida. Apenas Ihe acrescentou uma nova testada para construções. Para a abertura da rua dos Fazendeiros foi necessário derrubar pelo menos uma casa que ficara fora do novo alinhamento, a do morador Lourenço José da Cunha, o qual por isso pede 20 mil réis de ajuda para a Câmara, numerário esse necessário para reconstruir sua habitação, em $1858 .{ }^{90}$ Nessa rua dos Fazendeiros se instalou o Mercado cuja construção é anterior a 1879, posto que comparece no inventário desse ano da Baronesa de Paraitinga, como confinante de casas dela. ${ }^{91}$ O Mercado atual, no mesmo lugar, data de 1902.

É claro que nem o desenho da cidade resultante representa uma reprodução fiel daquele racionalismo hipodâmico que povoaria a cabeça do Morgado de Mateus, posto que alguma modificação foi introduzida pelas condições particulares dos povoadores de São Luís, como se verifica pelo que houve nos casos da matriz e da cadeia, ou pela introdução tumultuária de um edifício como o da igreja das Mercês, nem equivale ao predomínio completo daquele empirismo que fazia as cidades brasileiras serem literalmente desenhadas pelos caminhos e cruzamentos.

Do ponto de vista da arquitetura que encheu a cidade de São Luís há influências visíveis a olho nu. Influência da longínqua Côrte, que faz os mais abastados optarem pelo partido de sobrado, em construções cujo andar térreo era relegado às funções de acesso e depósito, desprezo este ao qual não seria estranho o perigo de enchentes, como aquela que inutilizou a cadeia, em 1863. A qualificação de status por via de residências pretenciosas era uma 


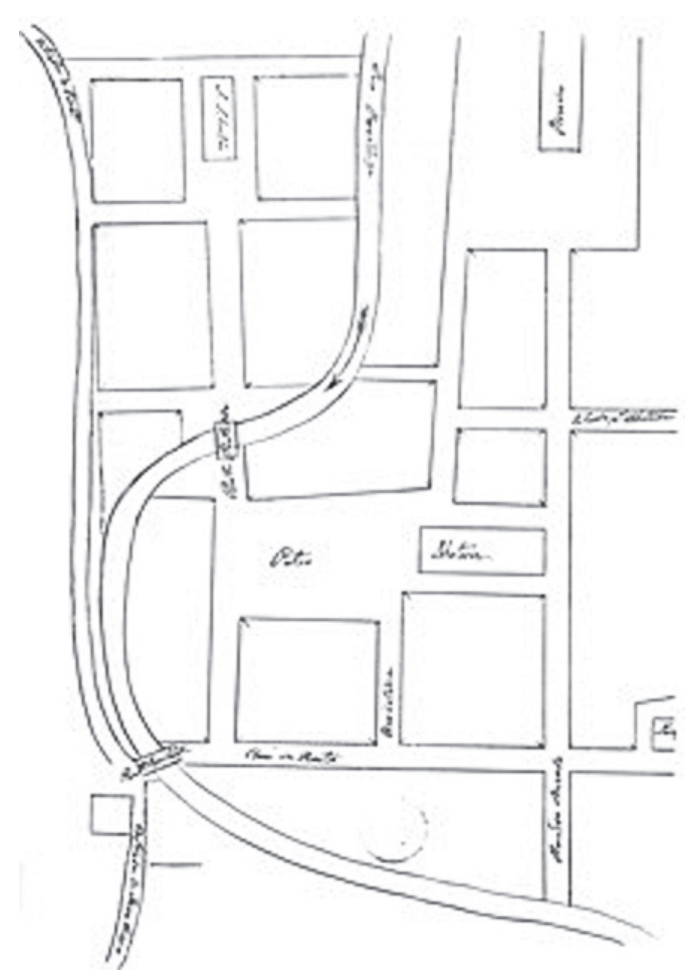

Figura 1: Planta do centro da cidade. Desenho a mão. Fonte:

79 Idem, idem.

80 Livro de Atas da Câmara, São Luís do Paraitinga (18411867), fl. 12, 4a sessão de 8.7.1841.

81 Livro de Vereanças, São Luís do Paraitinga (18151829), fls. $206 v$ e 207 , ano de 1826.

82 DAESP, Ofícios Diversos, São Luís do Paraitinga, cx. 471, ord. 1266, Pasta de 1840 (Of. de 16.3.1840); e cx. 470, ord. 1265, Pasta de 1838 (Of. de 15.10.1838).

83 "Lançamento da Receita da Dessima dos Predios Urbanos...", ano de 1841 .

84 DAESP, Ofícios Diversos, São Luís do Paraitinga cx. 471, ord. 1266, Pasta de 1844 (Of. de 7.9.1844).

85 DAESP, Ofícios Diversos, São Luís do Paraitinga, cx. ord. 1267, Pasta de 1852 (Of. de 17.3.1852) condição da classe dirigente do segundo reinado, o que fazia cada cidade pretender ser a Côrte, na observação de Zaluar. ${ }^{92}$ Atrás dessa influência da Côrte estava a experiência da arquitetura urbana de Minas Gerais, modelo disponível, seja pela presença dos próprios mineiros, seja porque havia carência de outros modelos. Não se deve esquecer contudo que a região do vale do Paraiba representa na arquitetura paulista a área de encontro dessa influência mineira aliada, especialmente na arquitetura do café, com a experiência dos engenhos da baixada fluminense, e a taipa de pilão. Especialmente nas cercanias dos Estados do Rio de Janeiro e Minas Gerais, as construções mais antigas, do começo do século XIX, têm um esquema construtivo baseado no embasamento de pedra e parte superior de pau-apique ou adobe, e uma solução central de gaiola.

A sede da fazenda Pedro Alves denuncia influência mineira, pelo partido geral, encostado no barranco, com um pavimento de "sobrado", dois alpendres e acesso pela frontaria, estrutura em gaiola com recheio de pau-a-pique, telhado com solução de prolongo e organização do espaço interno, com salas de travessia obrigatória mas sem corredores. O Salvador Alves Ferreira, que comprara as terras e residia nelas ${ }^{93}$, aparece no recenseamento de Ordenanças de 1805 como "soldado de a Cavalo", com 36 anos, solteiro, e planta para o consumo. No ano seguinte, ele aparece "cazado de novo" com Gertrudes Maria, como agricultor e miliciano, na "esquadra do Ribeirão". Em 1807 já tem um filho, e colheu milho, feijão, algodão e criou porcos. Em 1808 vendeu 15 capados. Já em 1811, Salvador aparece no Mapa dos Engenhos da Vila, tendo vendido 144 medidas de águas ardentes; tem 2 escravos. Em 1818 é apontado como agricultor em "seu engenho", com 4 escravos. Pelo maço de população de 1825 (Mapa dos Engenhos) os 10 engenhos de São Luís produziam apenas 526 barris, resultado pouco, que "estes ditos engenhos não trabalham efetivamente, porque seus donos mais se ocupam em outras lavouras que na de cana", por exemplo "lavoura de porcos", dizem lá. ${ }^{94}$ Procedia de Cunha, pelo que se conclui que o "mineiro" da sua habitação resultaria mais do construtor do que do dono. Tal hipótese é reforçada pelo fato de se ter encontrado na mesma região de São Luis outra sede de fazenda — a Pinheirinho - que, tudo leva a crer, desde o partido geral até os detalhes de tratamento da madeira, tenha sido obra do mesmo construtor. ${ }^{95} \mathrm{~A}$ Pinheirinho traz a diferença de, ao 
86 Levantamento IPHANCONDEPHAAT (São Luís do Paraitinga), 1972, arq. 4o Distrito - IPHAN, São Paulo.

87 DAESP, Ofícios Diversos, São Luís do Paraitinga, cx. 472, ord. 1267, Pasta de 1852 (Of. de 17.3.1852).

88 Livro do Registro Geral da Câmara, São Luís do Paraitinga (1828-1873), fls. 198v e 199, ano de 1902 .

89 DAESP, Ofícios Diversos, São Luís do Paraitinga, cx. 471 , ord. 1266 , ofício de 18.5.1888.

90 Livro de Atas da Câmara, São Luís do Paraitinga (1841-1867), fl. 85v, sessão de 30.8.1858.

91 Inventários, Cartório do 2.o Oficio, São Luís do Paraitinga, doc. 1058, ano 1879

92 ZALUAR (Augusto E.), Peregrinação Pela Província de São Paulo (1860-1861). Biblioteca Histórica Paulista, vol. II, São Paulo, 1953, pág. 50

93 DAESP, Tombamento (terras) de 1817, registro n. 20.

94 DAESP, População, São Luís do Paraitinga, cx. 159. ord. 159 e cx. 160, ord. 160, anos de respectivamente, 1803 a 1813 , e 1814 a 1830 .

95 DAESP, População, São Luís do Paraitinga, cx. 159, ord. 159, mss. de 1811, 2a Cia. de Ordenanças (indicação de um carpinteiro natural de Baependí, Minas Gerais, de idade de 23 anos).

96 Inventários, Cartório do 10 Ofício, São Luís do Parai-atinga, ano de 1861, 20 volume, de Joaquim José Ferreira.

97 Livro de Provimentos Gerais, posturas e contratos da Câmara, São Luís do Paraitinga, fl. 20v, § 4o, ano de 1854.

98 SAIA (Luís), op. cit., págs. 61 e segts.

99 Idem, págs. 173, 174 e 175. invés da solução de alpendre, oferecer uma sacada corrida.

O partido "de sobrado", com o pavimento principal parcialmente térreo, se converteu em tradição mineira, mesmo nos lugares onde o sítio não sugerisse tal solução. Embora tal partido fosse usual também nos engenhos do litoral norte de São Paulo, a sua aplicação em pontos desse Estado sem possibilidade alguma de contato com a marinha, como é o caso da sede da fazenda Jaborandi, em Altinópolis, quase na divisa de Minas Gerais, e da qual se sabe foi dos Garcia Figueiredo vindos de Minas, em torna viagem, para São Paulo, parece uma indicação aceitável de influência mineira. Mesmo porque essa influência se verifica nas mais antigas fazendas paulistas de café, procedentes sem dúvida da experiência das arquiteturas mineira e fluminense, como é o caso da fazenda Paud'Alho, em São José do Barreiro, de 1819. O mesmo partido, porém, com uma organização de espaço de influência paulista (alpendre entalado, central, entre capela e quarto de hóspede, sotão) encontrado em Paraibuna, apresentando um esquema construtivo de sobrado, gaiola, recheio de pau-a-pique, e acesso pela frontaria, mesmo aí é possível discernir uma influência mineira... no tratamento construtivo de um partido paulista. Tão paulista que se fôsse construído em taipa de pilão, como seria a solução mais corrente, não aceitaria de forma alguma a solução "de sobrado".

Como organização do espaço interno, com todos os compartimentos voltados para o exterior, também nisso a sede da fazenda Pedro Alves parece influência de mineiro. Na já citada sede da fazenda Paud'Alho, em São José do Barreiro, onde comparecem vários alpendres, os compartimentos se voltam invariavelmente para o exterior, mesmo que este exterior esteja alpendrado.

O prolongo do telhado é também uma solução geralmente afeiçoada pela arquitetura de Minas Gerais, principalmente pelo arquiteto rural. E é, em contrapartida, uma solução inusitada na arquitetura paulista.

Se o esquema construtivo, utilizado na fazenda Pedro Alves, comparece usualmente nas construções dos sobrados de São Luís, é verdade que ao lado das construções de taipa de pilão, das quais o exemplar local mais antigo é certamente a residência do Ajudante Joaquim José Ferreira, na rua Boa Vista, o mesmo não se poderia dizer do tipo de organização do espaço que fez praça na cidade, especialmente nos sobrados de frontaria voltada para as ruas. Vale a pena estabelecer um confronto entre esta construção de 1834 e a sede da fazenda Pedro Alves.

O Ajudante Ferreira procedia de Mogí das Cruzes. ${ }^{96}$ Sua residência é de taipa de pilão, tem alcovas, e um dos lados é de oitão, sem envasaduras. Este projeto tem procedência urbana, pois de outra forma não se explicaria nem sua fachada principal, de nítida feição citadina, nem a parede do oitão, cega, apesar das condições fáceis de aí abrir envasaduras. Mesmo que estivessem em vigor as posturas aprovadas em 1854, que mandam que "nenhuma porta ou janela se abrirão nos oitões das casas que tem saída para terrenos que tenham de ser ocupados com prédios (..) salvo quando se abram para quintais" ${ }^{\prime 97}$, a verdade é que a casa do Ajudante Joaquim desfrutava de $360^{\circ}$ de liberdade. Além disso, este mesmo Ajudante fez questão, para se furtar ao pagamento da Décima Urbana, de afirmar a sua casa como sede de uma produção rural. Não adiantou: ele paga a Décima Urbana.

Duas indicações podem ser extraídas do confronto acima: o paulista prefere, quando possível, o uso da taipa de pilão; e o faz usualmente para as paredes envoltórias e para uma parede interna, de travamento, o demais de pau-a-pique; o oitão cego é uma condição que conduz à solução de alcova. A primeira indicação é matéria de constatação, e vale para a arquitetura não bandeirista, isto é, do século XVIII em diante. No século XVII a residência do homem abastado de São Paulo tem todas as paredes de taipa de pilão, quer externas, quer internas. Esta preferência é largamente comprovada pelas residências paulistas do segundo século, já estudadas $^{98}$, inclusive, na sua ocorrência urbana, em Parnaíba (SP). ${ }^{99}$ Isto não exclui é verdade, a tradição de esquemas construtivos de pau-a-pique, tanto para as paredes do arcabouço, como para as paredes divisórias. O pau-a-pique, tantas vezes desavisadamente chamado de taipa, é solução universal, e usada por quase todos os povos. A taipa de pilão é, ao contrário, uma forma já elaborada pelos povos de vinculação mediterrânea, e sujeita, portanto, a determinadas leis de dessiminação e uso. É, por exemplo, uma solução aristocrática, 
pelo menos mais aristocrática que o tijolo, tanto o crú (adobe), como o cosido. No caso presente, trata-se de verificar em que medida tais soluções construtivas eram adotadas de um modo sistemático. $\mathrm{Na}$ arquitetura paulista de residência de abastados do século XVII e começo do XVIII, a taipa de pilão é uma solução sistemática; o pau-a-pique é eventual. Na construção paulista de residência do século XIX, especialmente residências das classes mais abastadas, a solução sistemática foi: paredes externas e uma parede interna, de travamento, de taipa de pilão; paredes internas, divisórias, de pau-a-pique. Em São Luís tal esquema se encontra largamente aplicado: na Praça Osvaldo Cruz, nas residências números 3, 21, 23 e 24; na rua 31 de Março, n 11, na rua Cel. Domingues de Castro, n 33; na rua Cônego Bueno, esquina da rua Monsenhor Gióia; na rua do Carvalho, no 14 e 9, e na rua Osvaldo Cruz, nº 4, que é a casa do Ajudante Joaquim e onde depois nasceu o cientista Osvaldo Cruz. Nem sempre, é claro, o esquema vem aplicado na sua totalidade; mas na maior parte dos casos ou se trata de uma solução onde o pavimento térreo é de taipa de pilão e o superior de pau-a-pique, ou se encontram modificações acrescidas ao projeto primitivo. No demais das construções mais volumosas, geralmente sobrados, o embasamento (se é que se poderia chamar de embasamento todo o pavimento térreo) é de pedra entaipada, especialmente com a disposição de colunas, e o restante de pau-a-pique. Esta última solução, tudo leva a acreditar que se trata de uma influência procedente do litoral ou das bandas do leste. Realmente, nesses lugares constituia uma prática usual. A notícia de uma inundação destruindo a antiga cadeia, em 1863, parece indicar que este perigo constituiria um obstáculo sério anteposto ao uso da taipa de pilão.

A condição do oitão cego levar à solução de alcova ou camarinha, isto é, um compartimento sem abertura para o exterior, é uma tese a ser estudada. Sempre tendo em vista as soluções sistemáticas, pode-se conjecturar desde logo, que a envasadura nos oitões teria levado a arquitetura residencial urbana do Nordeste brasileiro a uma evolução de tal modo elaborada que chegou a formular partidos que implicavam no "tratamento" arquitetônico dos oitões como fachadas... decoradas. Como aparece, por exemplo, na esplêndida casa de Feira de Santana, na Bahia, ou como é corrente na arquitetura nórdica transplantada para certas regiões do sul do Brasil, notadamente em Santa Catarina, na zona de influência alemã. Neste último caso a ocorrência é tanto urbana como rural; no Nordeste a tipicidade se restringe ao âmbito urbano.

No caso genérico da arquitetura residencial urbana paulista do século passado, o modelo ideal é o de um espaço residencial dividido em três lanços: o fronteiro, nobre, de salas ou quartos; o posterior, de estar, com sala de jantar; e o intermediário com alcovas que se abrem para um ou outro lanços extremos, ou para ambos; como apêndice, os serviços se instalavam num puxado, num dos lados da face posterior. Independente de ser sobrado ou não, uma considerável percentagem de habitações de sedes de fazendas paulistas do café mantem este esquema para a sua organização do espaço residencial, mesmo quando as condições favorecem a abertura de envasaduras laterais. Tudo leva a crer que a elaboração de tal partido tenha ocorrido no âmbito urbano, onde frequentemente a proibição de envasaduras nos oitões e a profundidade da área ocupada, levariam ao aproveitamento de uma faixa intermediária, cuja compleição construtiva, como que forçada pelos apôios para a estrutura do telhado, sugeria um espaço a trabalhar. A saida, facil e enganosa, de se lembrar a influência árabe depositando nos costumes nacionais um reclusionismo exagerado para as mulheres, se afigura inteiramente destituida de objetividade. Realmente não rende como explicação de coisa alguma. A pesquisa de uma sistemática equivalente nas cidades já então estabelecidas, no litoral ou em Minas, também não parece levar a nada. Nem naquele e especialmente neste caso de Minas o testemunho dos "restos" encontrados nega tal sistema. Em Minas, notadamente, de onde viria uma experiência urbana e rural bastante volumosa, o que ocorre é uma procura pertinaz de voltar os compartimentos para o exterior, às vezes abrindo vários páteos internos, como nos esplêndidos exemplares de plantas mineiras levantadas por Wasth Rodrigues. ${ }^{100}$ A alternativa, observada por Vauthier em Pernambuco, de especializar o espaço no sentido vertical, dando a cada pavimento uma função bem definida, também não encontra similar no sul, cuja arquitetura residêncial sempre demonstrou pouca desenvoltura neste sentido. Quanto à solução expressa pelo citado esquema, de três lanços com funções especialisadas bem definidas, é bem possível que seja encontrada mais de uma ocasião 
101 SPIX E MARTIUS, Viagem Pelo Brasil, Imprensa Nacional, Rio de Janeiro, 1938, 10 vol., pág. 193

102 MULLER (Daniel Pedro), Op. cit., pág. 43.

103 HOLANDA (Sérgio Buarque), História Geral da Civilização Brasileira (sob a direção de), Difusão Européia do Livro, São Paulo, 1967, Tomo 2, 20 vol., págs. 438 e 439 . eventualmente aplicada, tanto na zona urbana como nas residências rurais. Igualmente outras, como a da sala central, ou a dos páteos internos. Teria acontecido então o preceito evangélico: muitos serão os chamados e poucos os escolhidos. Dentre todas as propostas de organização do espaço interno das residências paulistas do século XIX, rurais ou urbanas, essa foi sem dúvida a escolhida, posto que sempre que foi possível se a encontra aplicada em inúmeras variantes, das quais a da casa do Ajudante Joaquim é uma e a dos sobrados da praça de São Luís é outra. Restaria entretanto observar que neste último caso o minguado da frontaria leva o esquema a uma expressão resumida que por pouco não o faz esquecer a fisionomia original. As residências Rua Barão do Paraitinga n 28 e Praça Osvaldo Cruz n 1, geminadas, e certamente construídas ao mesmo tempo, apresentam uma organização do espaço interno, no pavimento superior, perfeitamente enquadrada nessa fórmula: pelo caixão da escada estão separadas duas alcovas que ficam no miolo da construção, ladeadas pelo corredor e um compartimento que se abre para as duas salas, anterior e posterior. Nos fundos, as áreas de serviço, também geminadas, ocupam apenas uma parte da frontaria disponível. As variantes deste esquema resumido são realmente poucas. Mesmo naqueles edifícios que desfrutam de frontaria mais generosa, dando margem a uma sequência de camarinhas, se observa que todo o problema gira em torno do aproveitamento do espaço que sobra entre salas anterior e posterior. Na residência da Praça Osvaldo Cruz n²4, na qual se constata a aplicação mais ortodoxa do esquema paulista de construção no relativo aos edifícios de taipa de pilão, a disposição das camarinhas em série é apenas obstaculada pelos corredores de passagem e pelo caixão da escada. Qualquer que seja a variante aplicada em cada caso, é fundamental a condição deste espaço conter um apôio decisivo para a estrutura do telhado. Coisa equivalente ocorre nas casas térreas onde a aplicação do mesmo esquema espacial se verifica em inúmeros exemplos, embora neste caso de casas térreas surjam igualmente espaços organizados de modo a preferir compartimentos voltados para o exterior.

Nas casas populares, nas quais a pobreza e a pouquidão de compartimentos não impõe uma complexidade maior na organização do espaço, tudo se resume, na prática, a duas salas do extremo anterior e posterior e mais um compartimento intermediário, cego, ventilado pela telha-vã. Embora não se tenha encontrado nenhum exemplar de habitação com a antiga disposição da cozinha em alpendrado, nos fundos, como a que Martius encontrou em Taubaté ${ }^{101}$, algumas casas populares oferecem uma planta que sugere tenham sido os compartimentos dos fundos fechados em épocas mais recentes. O esquema primitivo seria: um compartimento na frontaria, uma passagem e um compartimento cego no lanço intermediário e um alpendrado nos fundos. Este último seria a cozinha ou, em geral, o dos serviços domésticos.

Embora São Luís do Paraitinga não possa ser considerada uma cidade característica da economia do café, economia essa responsável por cerca de 90\% das atuais cidades paulistas, posto que tangenciou apenas a problemática cafesista, como produção e como consequências urbanas, a verdade é que essa cidade representa um marco daquilo que posteriormente passaria a caracterizar as cidades nascidas e crescidas em função da produção do café. Realmente inaugura-se com o governo do Morgado de Mateus a preferência pela cidade em xadrez, de tipo hipodâmico, que vai fazer praça, no Estado de São Paulo e sul de Minas, na região que se povoou e viveu cem anos sob o signo do café.

O que teria levado a povoação à condição de "medíocre, apesar de ser antiga" no dizer de Daniel Pedro Muller, ${ }^{102}$ fosse o peso do recrutamento que se abatia sobre as vilas paulistas no início do século XIX, fosse o vulnerável de suas terras, postas rapidamente em incontornável decadência pelo estilo predatório da cultura cafesista, ou fosse ainda o fato de situar-se afastada da trama viária principal que acentuou a geografia humana da região paulista, a verdade é que os cincoenta anos de relativa vitalidade econômica foram insuficientes para estruturar uma unidade urbana capaz de um desenvolvimento autônomo do quadro de azares que perseguiram a economia colonial do café. Os motivos acima citados influiram, a cada um deles cabendo quota ponderável. A carência e a qualidade dos habitantes foi um fato que não pode ser desconsiderado. O repovoamento da província de São Paulo, sofreu sangrias sérias, pelo recrutamento, no início do século XIX. Por um documento de $1824{ }^{103}$, sabe-se que a província de São Paulo socorreu a fronteira do sul com 12.000 homens, e quatorze expedições. Além disso, cerca de 1.300 pessoas se bandearam para a Côrte. A isto 
104 Idem, idem.

105 DAESP, Ordenanças de São Luís e Ubatuba, cx. 59, ord. 298 , doc. 59-1-32

106 MULLER, (Daniel Pedro), Op. cit., pág. 241.

Figura 2: Sede da Fazenda Pedro Alves já desaparecida. Fonte: se somariam cerca de 16.000 paulistas desertores emigrados para as Minas Gerais "pelos contínuos e anuais recrutamentos". ${ }^{104}$ Nessa época, recruta era "a palavra que horroriza tanto a estes povos como a morte". 105

Nessas condições, em que pese a relativa pujança demográfica originada do surto local cafesista no entorno de 1850, responsável pela tentativa de loteamento do outro lado do rio Paraitinga, cedo as lavouras municipais foram alcançadas pelo cansaço do salmorão desprotegido de matas. A construção de sobrados nas áreas mais categorizadas da cidade, não revela uma riqueza equivalente ao que aconteceu noutras cidades do vale do rio Paraíba, nem significa a montagem de um equipamento urbano que delate riqueza mais permanente. Raro um indício ou outro de especial significado, como a existência de uma relativamente notável quantidade de ferreiros sediados na cidade. ${ }^{106}$ Isso se explicaria mais por São Luís se encontrar no roteiro de tropas cargueiras que trafegavam para a marinha, transportando a produção de outros municípios do vale. Com a entrada em cena da estrada de ferro, estaria decretada a irremediável decadência de São Luís, entregue então à sorte da produção local.

Apesar de toda essa aparente desimportância, São Luís do Paraitinga é, no quadro da ocupação do estado de São Paulo durante o século XIX, uma preliminar decisiva, na medida que expressa uma orientação que vai se firmar nas quinhentas cidades paulistas que vão ser fundadas em função da economia do café.

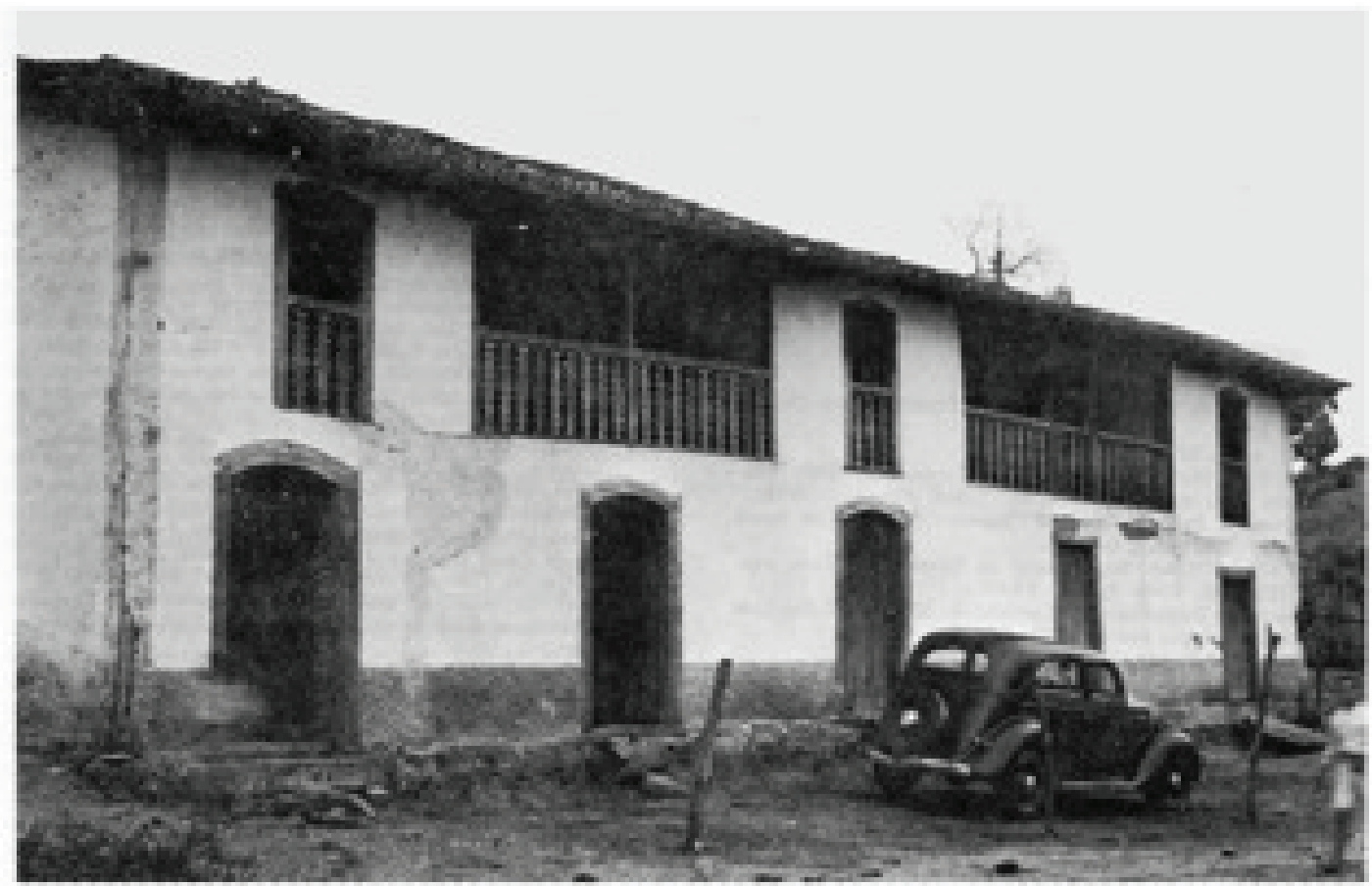

